\title{
Prevalence of obesity and associated cardiovascular risk: the DARIOS study
}

Francisco Javier Félix-Redondo ${ }^{1,2}$, María Grau ${ }^{3 *}$, José Miguel Baena-Díez ${ }^{3,4}$, Irene R Dégano ${ }^{3}$, Antonio Cabrera de León ${ }^{5}$, Maria Jesús Guembe ${ }^{6}$, María Teresa Alzamora ${ }^{7,8}$, Tomás Vega-Alonso9 Nicolás R Robles ${ }^{2,10}$, Honorato Ortiz ${ }^{11}$, Fernando Rigo ${ }^{12}$, Eduardo Mayoral-Sanchez ${ }^{13}$, Maria José Tormo ${ }^{14}$, Antonio Segura-Fragoso ${ }^{15}$ and Daniel Fernández-Bergés ${ }^{2,16}$

\begin{abstract}
Background: To estimate the prevalence of overweight and obesity in the Spanish population as measured with body mass index (BMI), waist circumference (WC) and waist to height ratio (WHtR) and to determine the associated cardiovascular risk factors.

Methods: Pooled analysis with individual data from 11 studies conducted in the first decade of the 21st century. Participants aged 35-74 years were asked about the history of cardiovascular diseases, hypertension, diabetes and hypercholesterolemia. Height, weight, WC, blood pressure, glycaemia, total cholesterol, low-density and high-density lipoprotein cholesterol and coronary risk were measured. The prevalence of overweight (BMl $25-29.9 \mathrm{~kg} / \mathrm{m}^{2}$ ), general obesity (BMI $\geq 30 \mathrm{~kg} / \mathrm{m}^{2}$ ), suboptimal WC ( $\geq 80 \mathrm{~cm}$ and $<88$ in women, $\geq 94$ and $<102$ in men), abdominal obesity (WC $\geq 88 \mathrm{~cm} \geq 102 \mathrm{~cm}$ in women and men, respectively) and WHtR $\geq 0.5$ was estimated, standardized for the European population.

Results: We included 28,743 individuals. The prevalence of overweight and suboptimal WC was $51 \%$ and $30 \%$ in men and $36 \%$ and $22 \%$ in women, respectively; general obesity was $28 \%$ in both sexes and abdominal obesity $36 \%$ in men and $55 \%$ in women. The prevalence of WHtR $\geq 0.5$ was $89 \%$ and $77 \%$ in men and women, respectively. All cardiovascular risk factors were significantly associated with abnormal increased values of BMI, WC and WHtR. Hypertension showed the strongest association with overweight [OR $=1.99$ (95\% confidence interval 1.81-2.21) and $O R=2.10(1.91-2.31)]$; suboptimal $W C[O R=1.78(1.60-1.97)$ and $O R=1.45(1.26-1.66)]$, with general obesity $[\mathrm{OR}=4.50$ (4.02-5.04), and $\mathrm{OR}=5.20(4.70-5.75)]$ and with $\mathrm{WHtR} \geq 0.5[\mathrm{OR}=2.94(2.52-3.43)$, and $\mathrm{OR}=3.02$ (2.66-3.42)] in men and women respectively, besides abdominal obesity in men only [OR $=3.51$ (3.18-3.88)]. Diabetes showed the strongest association with abdominal obesity in women $[\mathrm{OR}=3,86(3,09-4,89)$.

Conclusions: The prevalence of obesity in Spain was high. Overweight, suboptimal WC, general, abdominal obesity and WHtR $\geq 0.5$ was significantly associated with diabetes, hypertension, hypercholesterolemia and coronary risk. The use of lower cut-off points for both BMI and particularly WC and could help to better identify the population at risk and therefore achieve more effective preventive measures.
\end{abstract}

Keywords: Cardiovascular diseases, Obesity, Prevalence, Risk factors

\footnotetext{
* Correspondence: mgrau@imim.es

${ }^{3}$ Grupo de Epidemiología y Genética Cardiovascular, Programa de Investigación en Procesos Inflamatorios y Cardiovasculares, IMIM (Institut Hospital del Mar d'Investigacions Mèdiques), Barcelona, Spain

Full list of author information is available at the end of the article
} 


\section{Background}

Cardiovascular diseases are the leading cause of death worldwide [1]. However, the decreasing trend observed in population cardiovascular mortality in recent years has been explained by changes in the prevention and control of cardiovascular risk factors and by the use of more effective medical and surgical treatments [2]. The increasing prevalence of obesity recently observed in Spain may have diluted to some extent the effect of other cardiovascular risk factors control to decrease coronary disease deaths [3-6].

The available evidence indicates that general obesity, measured with body mass index, and abdominal obesity, whether measured with waist circumference only or waist circumference corrected with height, are associated with coronary disease risk and mortality [7-10].

The prevalence of general and abdominal obesity has been recently studied in a national sample of Spanish general (>18 years) and elderly ( $\geq 65$ years) population $[11,12]$ and in regional samples [13-18]. However, the association of both types of obesity with the 10-year coronary disease risk estimated with the Framingham-REGICOR risk functions validated for the Spanish population [19] has not been studied in depth. The knowledge of this association may help to elucidate the excess risk presented by the population with overweight, general and abdominal obesity compared with the general population. This association may be particularly important in individuals aged 35 to 74 years, in whom the strategies of primary prevention of cardiovascular disease seem to be more effective [20].

The aims of this study are: (1) to estimate in the Spanish population aged 35 to 74 years the prevalence of overweight, general and abdominal obesity and (2) to estimate their association with cardiovascular risk factors and 10-year coronary disease risk as measured with the Framingham-REGICOR risk functions.

\section{Methods}

\section{Study population}

Pooled analysis with individual data from 11 populationbased studies conducted in 10 geographical areas of Spain since 2000 with similar methodological designs. The methodology has been described elsewhere [21]. Briefly, participants were 35 to 74 years old and gave written informed consent to take part in the component studies. The DARIOS study (Dyslipemia, Atherosclerotic Risk, Increased high sensitivity C-reactive protein, and inflammatory and Oxidative status in Spanish population) was approved by the Municipal Healthcare Institute's Clinical Research Ethics Committee (authorization nº 2009/3640).

\section{Anthropometric measurements}

Waist circumference (WC), weight and height were measured with participants in underwear and barefoot.
Body mass index (BMI) was determined as weight divided by squared height $\left(\mathrm{kg} / \mathrm{m}^{2}\right)$ and waist-to-height ratio (WHtR) as waist circumference $(\mathrm{cm})$ divided by height (cm). All participants were classified according to BMI: (1) normal weight, BMI $<25 \mathrm{~kg} / \mathrm{m}^{2}$; (2) overweight, BMI $25-29.9 \mathrm{~kg} / \mathrm{m}^{2}$; and (3) general obesity, BMI $\geq 30 \mathrm{~kg} / \mathrm{m}^{2}$; according to WC: (1) optimal, WC $<94 \mathrm{~cm}$ in men and $<80 \mathrm{~cm}$ in women(2) suboptimal, WC 94-102 cm in men and WC 80-88 cm in women; and (3) abdominal obesity, $W C \geq 102 \mathrm{~cm}$ in men and $W C \geq 88 \mathrm{~cm}$ in women [22,23]; and according to WHtR: $(1)<0.5$ and (2) $\geq 0.5[24,25]$.

\section{Other measurements}

Standardized questionnaires were used to collect sociodemographic and lifestyle variables, and the previous history of cardiovascular disease (coronary artery disease and stroke) and treatments for diabetes, hypertension and hypercholesterolemia. Current smoking was defined as actively smoking within the preceding year.

Prevalence of hypertension, diabetes and hypercholesterolemia was considered if the participant had been diagnosed, was treated for these disorders or presented with systolic blood pressure $\geq 140 \mathrm{mmHg}$ or diastolic blood pressure $\geq 90 \mathrm{mmHg}$, glycaemia $\geq 126 \mathrm{mg} / \mathrm{dl}$ or total cholesterol $\geq 240 \mathrm{mg} / \mathrm{dl}$, respectively.

Blood pressure was measured with a periodically calibrated sphygmomanometer. A cuff adapted to upper arm perimeter (young, adult, obese) was selected for each participant. Measurements were performed in a seated position after a 5-minute rest. Two measurements were taken and the mean value was recorded for the study.

Blood samples were taken following $>10 \mathrm{~h}$ fast. Analysis was performed in local laboratories on fresh blood or aliquots of serum stored at $-80^{\circ} \mathrm{C}$ in samples not previously thawed. Triglycerides, glucose, total and high-density lipoprotein (HDL) cholesterol were measured using standard methods. When triglycerides were $<300 \mathrm{mg} / \mathrm{dL}$, low density lipoprotein (LDL) cholesterol was calculated using the Friedewald formula. Analysis of concordance of lipid profile results using a reference laboratory was performed to correct the few deviations observed [21].

Cardiovascular risk in all participants aged 35 to 74 years with no history of cardiovascular disease was calculated with the REGICOR function adapted from the original Framingham function and validated for the Spanish population [19].

\section{Statistical analysis}

The mean value of BMI, WC and WHtR and the prevalence of the corresponding categories were calculated by sex, standardized for the European age distribution [26] and accompanied by the $95 \%$ confidence interval. 
We summarized the baseline characteristics in three groups based on categories of BMI (i.e. normal weight, overweight and general obesity), WC ( optimal, suboptimal and abdominal obesity) and WHtR $(<0.5$ and $\geq 0.5)$, using percentages for categorical data, means and standard deviations for normally distributed data, and median and interquartile range when the distribution departed from normal (e.g., glycaemia and triglycerides). We tested for differences and linear trend using Student $t$ test, U-Mann Whitney and $x^{2}$ as appropriate.

To determine whether the associations found between BMI, WC and WHtR categories, and between cardiovascular risk factors and coronary risk were independent of age, we fitted multinomial logistic regression models adjusted for age.

Statistical analysis was done with R Statistical Package (R Foundation for Statistical Computing, Vienna, Austria; Version 2.15.0).

\section{Results}

The study enrolled 28,887 participants from 11 epidemiological studies from 10 autonomous communities. Table 1 presents the mean BMI, WC and WHtR and the prevalence of general and abdominal obesity standardized to the European population. The prevalence in each component study of DARIOS is shown in Additional file 1 : Tables S1 and S2.

The prevalence of cardiovascular risk factors significantly increased with BMI category (normal weight, overweight, general obesity), except for smoking and HDL cholesterol,

Table 1 Mean and distribution by categories of body mass index and waist circumference for men and women, standardized to the European population

\begin{tabular}{|c|c|c|}
\hline & $\begin{array}{c}\text { Men } \\
N=13,425\end{array}$ & $\begin{array}{c}\text { Women } \\
N=15,462\end{array}$ \\
\hline BMI $\left(\mathrm{kg} / \mathrm{m}^{2}\right)$, mean $(95 \% \mathrm{Cl})$ & $28.1(28.0-28.1)$ & $27.5(27.5-27.6)$ \\
\hline \multicolumn{3}{|l|}{$\begin{array}{l}\text { BMI categories, summarized, } \% \\
(95 \% \mathrm{Cl})\end{array}$} \\
\hline Normal weight $(<25)$ & $21.3(20.6-22.1)$ & $36.1(35.4-36.8)$ \\
\hline Overweight (25-29.9) & $50.7(49.8-51.5)$ & $35.6(34.9-36.4)$ \\
\hline General obesity $(\geq 30)$ & $28.0(27.2-28.8)$ & $28.3(27.6-29)$ \\
\hline Waist circumference $(\mathrm{cm})$, mean & $98.2(98.0-98.4)$ & $90.2(90.0-90.4)$ \\
\hline \multicolumn{3}{|l|}{$\begin{array}{l}\text { Waist circumference categories, } \\
\text { summarized, \% (95\% Cl) }\end{array}$} \\
\hline Men <94 cm; Women <80 cm & $33.8(32.9-34.7)$ & $23.5(22.8-24.2)$ \\
\hline $\begin{array}{l}\text { Men } \geq 94 \text { and }<102 \mathrm{~cm} \text {; Women } \geq 80 \\
\text { and }<88 \mathrm{~cm}\end{array}$ & $30.4(29.6-31.3)$ & $21.9(21.2-22.6)$ \\
\hline Men $\geq 102 \mathrm{~cm}$; Women $\geq 88 \mathrm{~cm}$ & $35.8(34.9-36.7)$ & $54.6(53.8-55.4)$ \\
\hline Waist-to-height ratio, mean & $0.59(0.58-0.60)$ & $0.57(0.57-0.58)$ \\
\hline Waist-to-height ratio $\geq 0.5, \%$ (95\% Cl) & $89.1(88.5-89.7)$ & $77.3(76.6-78.0)$ \\
\hline
\end{tabular}

ATPIII, Adult Treatment Panel III, BMI body mass index, $\mathrm{Cl}$ confidence interval. which significantly decreased in both men and women (Table 2). Similar results were found when we compared the prevalence of risk factors in different WC categories (Table 3) and WHtR (Additional file 1: Table S3).

Overweight, suboptimal WC, general and abdominal obesity and high WHtR were associated with diabetes, hypertension, hypercholesterolemia and coronary risk independently of age in both sexes. The magnitude of these associations was higher in women than in men in all instances, except for hypercholesterolemia and the suboptimal WC category, which were higher in men (Tables 4, 5 and 6).

In men, coronary risk was directly related to increased $\mathrm{BMI}$ in the $\mathrm{WC}<94$ category but increased in parallel with WC for all BMI categories. Notably, the highest mean coronary risk (7.6\%) was identified in men with abdominal obesity and normal weight; however, only $0.2 \%$ of the sample presented this phenotype. In women, coronary risk increased with both WC and BMI. On the other hand, the risk of all individuals with WHtR $\geq 0.5$ increased in parallel with BMI. Those with WHtR $<0.5$ presented minimal differences in coronary risk across BMI categories (Figure 1).

\section{Discussion}

The present study showed that almost $80 \%$ and $65 \%$ of Spanish men and women, respectively, weigh more than the recommended values for their height. Indeed, $28 \%$ of men and women presented general obesity, $36 \%$ of men and $55 \%$ of women presented abdominal obesity, and $89 \%$ of men and $77 \%$ of women have a WHtR $\geq 0.5$. Our results also showed a significant association independent of age between the obesity measures and cardiovascular risk factors (e.g., diabetes, hypertension and hypercholesterolemia). As a result, 10-year coronary disease risk significantly increased with the categories of BMI, WC and WHtR, which could indicate an important disease burden in coming years.

\section{Comparison with previous studies}

The main Spanish study on cardiovascular risk factors (DORICA study) conducted between 1990 and 2000 in individuals aged 25-60 years reported a general obesity prevalence of $13 \%$ in men and $18 \%$ in women [27], lower than the DARIOS results in data collected since 2000. This supports the increasing trend in the prevalence of obesity evidenced in other studies [2-5]. On the other hand, the prevalence of general and abdominal obesity was lower in the nationwide ENRICA Study conducted between 2008 and 2010 than in DARIOS. The age ranges of the populations studied ( $>18$ years in ENRICA and 35-74 years in DARIOS) may account for these differences [11]. However, since 2004 two studies have reported age-specific prevalence of general obesity in the Spanish elderly population 
Table 2 Population baseline characteristics by sex and body mass index category

\begin{tabular}{|c|c|c|c|c|c|}
\hline Men & Normal weight $\mathrm{N}=2,760$ & Overweight $\mathrm{N}=6,810$ & Obesity $N=3,801$ & $\mathrm{p}$-value & $\mathrm{p}$ for linear trend \\
\hline Age, years, mean (SD) & $51(12)$ & $54(11)$ & $55(11)$ & $<0.001$ & $<0.001$ \\
\hline Current smoker & $1138(41.2 \%)$ & $2089(30.7 \%)$ & $1094(28.8 \%)$ & $<0.001$ & $<0.001$ \\
\hline Systolic blood pressure, mean (SD) & $127(18)$ & $134(18)$ & $139(18)$ & $<0.001$ & $<0.001$ \\
\hline Diastolic blood pressure, mean (SD) & $77(10)$ & $81(10)$ & $84(11)$ & $<0.001$ & $<0.001$ \\
\hline Hypertension & $861(31.4 \%)$ & $3389(50.0 \%)$ & $2594(68.4 \%)$ & $<0.001$ & $<0.001$ \\
\hline Glycaemia, median [IQR] & 93 [87-101] & 98 [90-108] & $103[94-118]$ & $<0.001$ & $<0.001$ \\
\hline Diabetes & $239(8.7 \%)$ & $1066(15.7 \%)$ & $965(25.5 \%)$ & $<0.001$ & $<0.001$ \\
\hline Total cholesterol, mean (SD) & $210(38)$ & $215(39)$ & $215(40)$ & $<0.001$ & $<0.001$ \\
\hline HDL cholesterol, mean (SD) & $53(12)$ & $49(11)$ & $46(10)$ & $<0.001$ & $<0.001$ \\
\hline LDL cholesterol, mean (SD) & $135(34)$ & $140(35)$ & $138(34)$ & $<0.001$ & 0.004 \\
\hline Triglycerides, median [IQR] & $96[74-131]$ & 114 [86-158] & 134 [99-192] & $<0.001$ & $<0.001$ \\
\hline Hypercholesterolemia & $1016(37.1 \%)$ & $3204(47.4 \%)$ & 1975 (52.3\%) & $<0.001$ & $<0.001$ \\
\hline History of CV disease & $121(4.5 \%)$ & $446(6.8 \%)$ & $338(9.2 \%)$ & $<0.001$ & $<0.001$ \\
\hline Waist circumference, mean (SD) & $87(7)$ & $97(7)$ & $110(9)$ & $<0.001$ & $<0.001$ \\
\hline Waist-to-height ratio, mean (SD) & $0.51(0.05)$ & $0.57(0.04)$ & $0.65(0.05)$ & $<0.001$ & $<0.001$ \\
\hline 10-year CAD risk, median [IQR] & $2.8[1.5-5.2]$ & $4.0[2.3-7.1]$ & $5.2[3.0-8.3]$ & $<0.001$ & $<0.001$ \\
\hline 10-year CAD risk $\geq 10 \%$ & $166(6.6 \%)$ & $716(11.9 \%)$ & $551(16.7 \%)$ & $<0.001$ & $<0.001$ \\
\hline Women & Normal weight $N=5,244$ & Overweight $N=5,557$ & Obesity $N=4,571$ & p-value & $p$ for linear trend \\
\hline Age, years, mean (SD) & $48(10)$ & $55(11)$ & $57(10)$ & $<0.001$ & $<0.001$ \\
\hline Current smoker & $1546(29.5 \%)$ & $955(17.2 \%)$ & $481(10.5 \%)$ & $<0.001$ & $<0.001$ \\
\hline Systolic blood pressure, mean (SD) & $117(18)$ & $128(20)$ & $137(20)$ & $<0.001$ & $<0.001$ \\
\hline Diastolic blood pressure, mean (SD) & $73(10)$ & $78(10)$ & $82(10)$ & $<0.001$ & $<0.001$ \\
\hline Hypertension, (\%) & $1001(19.2 \%)$ & $2391(43.3 \%)$ & 3035 (66.6) & $<0.001$ & $<0.001$ \\
\hline Glycaemia, median [IQR] & 89 [83-95] & $92[86-101]$ & $98[90-111]$ & $<0.001$ & $<0.001$ \\
\hline Diabetes & $242(4.6 \%)$ & $572(10.3 \%)$ & $982(21.6 \%)$ & $<0.001$ & $<0.001$ \\
\hline Total cholesterol, mean (SD) & $209(38)$ & $218(39)$ & $218(38)$ & $<0.001$ & $<0.001$ \\
\hline HDL cholesterol, mean (SD) & $61(13)$ & $57(13)$ & $54(12)$ & $<0.001$ & $<0.001$ \\
\hline LDL cholesterol, mean (SD) & $131(34)$ & $140(34)$ & 139 (34) & $<0.001$ & $<0.001$ \\
\hline Triglycerides, median [IQR] & 78 [62-101] & $96[73-128]$ & 117 [88-157] & $<0.001$ & $<0.001$ \\
\hline Hypercholesterolemia & $1821(35.0 \%)$ & $2610(47.3 \%)$ & $2383(52.5 \%)$ & $<0.001$ & $<0.001$ \\
\hline History of CV disease & $108(2.1 \%)$ & $211(4.0 \%)$ & $239(5.4 \%)$ & $<0.001$ & $<0.001$ \\
\hline Waist circumference, mean (SD) & $79(9)$ & $90(8)$ & $104(10)$ & $<0.001$ & $<0.001$ \\
\hline Waist-to-height ratio, mean (SD) & $0.49(0.06)$ & $0.58(0.06)$ & $0.67(0.07)$ & $<0.001$ & $<0.001$ \\
\hline 10-year CAD risk, median [IQR] & $1.2[0.5-2.3]$ & $2.4[1.3-3.9]$ & $3.5[2.1-5.3]$ & $<0.001$ & $<0.001$ \\
\hline 10-year CAD risk $\geq 10 \%$ & $24(0.5 \%)$ & $83(1.6 \%)$ & $185(4.5 \%)$ & $<0.001$ & $<0.001$ \\
\hline
\end{tabular}

CAD Coronary artery disease, CV Cardiovascular, HDL High-density Lipoprotein, IQR Interquartile Range, LDL Low-density lipoprotein, SD Standard Deviation.

$[28,29]$ that is similar to DARIOS results. Since age is one of the main determinants of obesity, the prevalence is likely to increase as the population ages dramatically in coming years. The high prevalence of WHtR $\geq 0.5$ observed could be related to the threshold chosen, which has been internationally recommended [25]. However, a higher threshold (0.55) better discriminated cardiovascular risk in a population with high prevalence of obesity [18].
An international study by Doak et al. showed that Romanian men and Bulgarian women aged 25-64 years presented the lowest prevalence of obesity among European countries (10\%). On the contrary, Scottish men and women presented the highest prevalence $(28 \%$ and $26 \%$, respectively) [30], similar to the DARIOS results. Finally, analysis of National Health and Nutrition Examination Survey (NHANES) data showed that the prevalence in the US 
Table 3 Baseline characteristics by sex and categories of waist circumference

\begin{tabular}{|c|c|c|c|c|c|}
\hline \multirow[t]{2}{*}{ Men } & \multicolumn{3}{|c|}{ Waist circumference } & \multirow[b]{2}{*}{ p-value } & \multirow[b]{2}{*}{$p$ for linear trend } \\
\hline & $<94 \mathrm{~cm} \mathrm{~N}=3,702$ & $\geq 94$ and $<102 \mathrm{~cm} \mathrm{~N}=3,473$ & $\geq 102 \mathrm{~cm} \mathrm{~N}=4,215$ & & \\
\hline Age, mean (SD) & $50(11)$ & $54(11)$ & $56(11)$ & $<0.001$ & $<0.001$ \\
\hline Current smoker & $1406(38.0 \%)$ & 1035 (29.8\%) & $1280(30.4 \%)$ & $<0.001$ & $<0.001$ \\
\hline Systolic blood pressure, mean (SD) & $128(17)$ & $134(18)$ & $140(18)$ & $<0.001$ & $<0.001$ \\
\hline Diastolic blood pressure, mean (SD) & $78(10)$ & $81(10)$ & $84(11)$ & $<0.001$ & $<0.001$ \\
\hline Hypertension & $1219(33.1 \%)$ & $1764(51.0 \%)$ & $2894(68.8 \%)$ & $<0.001$ & $<0.001$ \\
\hline Glycaemia (mg/dl), median [IQR] & 94 [88-102] & 99 [91-109] & $103[93-117]$ & $<0.001$ & $<0.001$ \\
\hline Diabetes & $330(8.9 \%)$ & $539(15.6 \%)$ & $1038(24.8 \%)$ & $<0.001$ & $<0.001$ \\
\hline Total cholesterol (mg/dl), mean (SD) & $212(38)$ & $217(39)$ & $214(40)$ & $<0.001$ & 0.021 \\
\hline HDL cholesterol (mg/dl), mean (SD) & $51(12)$ & $49(10)$ & $47(10)$ & $<0.001$ & $<0.001$ \\
\hline LDL cholesterol (mg/dl), mean (SD) & $138(34)$ & $141(34)$ & $138(34)$ & $<0.001$ & 0.884 \\
\hline Triglycerides (mg/dl), median [IQR] & 102 [78-139] & $120[88-165]$ & 132 [97-188] & $<0.001$ & $<0.001$ \\
\hline Hypercholesterolemia & $1438(39.1 \%)$ & 1710 (49.7\%) & $2181(52.0 \%)$ & $<0.001$ & $<0.001$ \\
\hline History of CV disease & $150(4.2 \%)$ & $192(5.8 \%)$ & $402(10.0 \%)$ & $<0.001$ & $<0.001$ \\
\hline Body mass index $\left(\mathrm{kg} / \mathrm{m}^{2}\right)$, mean (SD) & $24.7(2.4)$ & $27.7(2.1)$ & $31.7(3.5)$ & $<0.001$ & $<0.001$ \\
\hline Waist-to-height ratio, mean (SD) & $0.51(0.04)$ & $0.58(0.03)$ & $0.65(0.05)$ & $<0.001$ & $<0.001$ \\
\hline 10-year CAD risk, median [IQR] & $2.8[1.6-4.9]$ & $4.1[2.3-7.1]$ & $5.4[3.2-8.6]$ & $<0.001$ & $<0.001$ \\
\hline 10-year CAD risk $\geq 10 \%$ & $184(5.4 \%)$ & $352(11.4 \%)$ & $650(18.2 \%)$ & $<0.001$ & $<0.001$ \\
\hline Women & $<80 \mathrm{~cm} \mathrm{~N}=2,900$ & $\geq 80 \mathrm{~cm}$ and $<88 \mathrm{~N}=2,800$ & $\geq 88 \mathrm{~cm} \mathrm{~N}=7,434$ & p-value & \\
\hline Age, mean (SD) & $46(9)$ & $51(10)$ & $57(11)$ & $<0.001$ & $<0.001$ \\
\hline Current smoker & $918(31.7 \%)$ & $671(24.0 \%)$ & 1019 (13.7\%) & $<0.001$ & $<0.001$ \\
\hline Systolic blood pressure, mean (SD) & $115(16)$ & $122(19)$ & $134(20)$ & $<0.001$ & $<0.001$ \\
\hline Diastolic blood pressure, mean (SD) & $72(10)$ & $75(10)$ & $80(10)$ & $<0.001$ & $<0.001$ \\
\hline Hypertension & $465(16.1 \%)$ & $808(29.0 \%)$ & $4289(57.9 \%)$ & $<0.001$ & $<0.001$ \\
\hline Glycaemia (mg/dl), median [IQR] & 88 [83-94] & 90 [85-97] & 96 [88-107] & $<0.001$ & $<0.001$ \\
\hline Diabetes & $87(3.0 \%)$ & $151(5.4 \%)$ & $1312(17.8 \%)$ & $<0.001$ & $<0.001$ \\
\hline Total cholesterol (mg/dl), mean (SD) & $206(36)$ & $215(37)$ & $219(38)$ & $<0.001$ & $<0.001$ \\
\hline HDL cholesterol (mg/dl), mean (SD) & $61(13)$ & $59(12)$ & $55(12)$ & $<0.001$ & $<0.001$ \\
\hline LDL cholesterol (mg/dl), mean (SD) & $129(32)$ & $137(33)$ & $139(34)$ & $<0.001$ & $<0.001$ \\
\hline Triglycerides (mg/dl), median [IQR] & 75 [60-95] & $86[68-114]$ & 109 [82-149] & $<0.001$ & $<0.001$ \\
\hline Hypercholesterolemia & $881(30.5 \%)$ & $1163(42.0 \%)$ & 3807 (51.5\%) & $<0.001$ & $<0.001$ \\
\hline History of CV disease & $69(2.5 \%)$ & $86(3.2 \%)$ & $326(4.6 \%)$ & $<0.001$ & $<0.001$ \\
\hline Body mass index $\left(\mathrm{kg} / \mathrm{m}^{2}\right)$, mean (SD) & $22.7(2.4)$ & $25.3(2.5)$ & $30.9(4.8)$ & $<0.001$ & $<0.001$ \\
\hline Waist-to-height ratio, mean (SD) & $0.46(0.03)$ & $0.53(0.03)$ & $0.64(0.07)$ & $<0.001$ & $<0.001$ \\
\hline 10-year CAD risk, median [IQR] & $0.9[0.5-1.9]$ & $1.7[0.8-3.1]$ & $3.1[1.7-4.9]$ & $<0.001$ & $<0.001$ \\
\hline 10-year CAD risk $\geq 10 \%$ & $9(0.3 \%)$ & $17(0.7 \%)$ & $229(3.4 \%)$ & $<0.001$ & $<0.001$ \\
\hline
\end{tabular}

Abbreviation: CAD Coronary artery disease, CV Cardiovascular, HDL High-density Llipoprotein, IQR Interquartile range, LDL low-density lipoprotein, SD Standard deviation.

is around $32 \%$ [31]. The authors attributed the differences to the socioeconomic context of the countries studied [30].

\section{Cardiovascular risk factors, obesity and sex}

Obesity is key in the development of hypertension and diabetes [32,33]. Indeed, both diseases were associated with general and abdominal obesity in the DARIOS data, independently of age. Hypercholesterolemia also showed a significant but weaker association, even though obese individuals in our sample presented the classical lipid disorder of hypertriglyceridemia and low HDL cholesterol [34].

In several population-based studies and a meta-analysis, the different measures of obesity were better discriminators 
Table 4 Age-adjusted odds ratio of overweight and general obesity for cardiovascular risk factors by sex

\begin{tabular}{|c|c|c|c|c|c|c|c|c|}
\hline & \multicolumn{4}{|c|}{ Overweight (BMI $\geq 25$ and $<30$ ) } & \multicolumn{4}{|c|}{ General obesity $(\mathrm{BMI} \geq 30$ ) } \\
\hline & \multirow{2}{*}{$\begin{array}{c}\text { Men } \\
\text { OR (Cl 95\%) }\end{array}$} & \multicolumn{3}{|c|}{ Women } & \multirow{2}{*}{$\begin{array}{c}\text { Men } \\
\text { OR (Cl 95\%) }\end{array}$} & \multicolumn{3}{|c|}{ Women } \\
\hline & & p-value & OR (Cl 95\%) & p-value & & p-value & OR (Cl 95\%) & $\mathrm{p}$-value \\
\hline Age (1 year) & $1.02(1.02-1.03)$ & $<0.001$ & $1.06(1.06-1.06)$ & $<0.001$ & $1.03(1.03-1.04)$ & $<0.001$ & $1.09(1.08-1.09)$ & $<0.001$ \\
\hline Diabetes & $1.71(1.47-1.99)$ & $<0.001$ & $2.53(2.28-2.81)$ & $<0.001$ & $3.08(2.64-3.60)$ & $<0.001$ & $2.95(2.56-3.40)$ & $<0.001$ \\
\hline Hypertension & $1.99(1.81-2.21)$ & $<0.001$ & $2.10(1.91-2.31)$ & $<0.001$ & $4.50(4.02-5.04)$ & $<0.001$ & $5.20(4.70-5.75)$ & $<0.001$ \\
\hline Hypercholesterolemia & $1.45(1.32-1.58)$ & $<0.001$ & $1.14(1.05-1.24)$ & 0.002 & $1.73(1.57-1.92)$ & $<0.001$ & $1.22(1.17-1.34)$ & $<0.001$ \\
\hline Coronary risk (1 percentage point) & $1.11(1.08-1.13)$ & $<0.001$ & $1.34(1.30-1.39)$ & $<0.001$ & $1.18(1.16-1.20)$ & $<0.001$ & $1.58(1.53-1.63)$ & $<0.001$ \\
\hline
\end{tabular}

Prevalence of hypertension, diabetes and hypercholesterolemia was considered if the participant was diagnosed, treated for these disorders or presented with systolic blood pressure $\geq 140 \mathrm{mmHg}$ or diastolic blood pressure $\geq 90 \mathrm{mmHg}$, glycaemia $\geq 126 \mathrm{mg} / \mathrm{dl}$ or total cholesterol $\geq 240 \mathrm{mg} / \mathrm{dl}$, respectively.

and had a stronger association with cardiometabolic risk factors in women [10,18,24,25,35].

The sedentary life-style could be a possible cause, which is more prevalent in Spanish women than in men [36]. In addition, sex-related differences in fat distribution [37] and in eating behaviours [38] may play a key role. Further cohort studies are needed to ascertain sexrelated differences in the use of these variables as predictors of cardiovascular events.

\section{Cardiovascular risk and obesity}

A recent study has shown improved coronary risk prediction in men if a general obesity diagnosis is included [39], and higher mortality has been associated with overweight, general and abdominal obesity in men [40]. In DARIOS results, the baseline coronary risk was higher in men, although 10-year coronary disease risk was strongly associated with overweight, general and abdominal obesity in women as well. Previous studies in Spain report that obesity did not increase the incidence of cardiovascular events; however, further cohort studies with longer follow-up are needed [41,42]. In the Framingham Heart Study, for instance, obesity was associated with increased relative risk for development of cardiovascular disease in a population aged 35-75 and followed for 44 years [43].

\section{Coronary risk and obesity types}

Finally, there is some controversy about the obesity measurement (i.e., general or abdominal) that better correlates to cardiovascular risk $[18,24,25,35,44,45]$. The abdominal obesity measures were significant predictors of cardiovascular events and death; BMI was not [10].

In our results, increased WC and WHtR implied higher coronary risk independently of BMI category. Surprisingly, men with $\mathrm{WC} \geq 102 \mathrm{~cm}$ and $\mathrm{BMI}<25 \mathrm{~kg} / \mathrm{m}^{2}$ presented the highest 10-year coronary disease risk. This finding could be explained by the sparse number of individuals included in this category. However, the subcutaneous fat storage in patients with high BMI seems to diminish cardiovascular risk compared to individuals with higher perivisceral fat storage [46]. Another possible explanation may be the presence of sarcopenic obesity (i.e., age-related body composition changes characterized by decreased skeletal muscle mass and increased body fat mass) [47] that is more associated with cardiometabolic risk [48] and mortality in individuals with coronary heart disease [49]. Both explanations may show the incapacity of the subcutaneous fat storage in these individuals due to genetics, ageing, sedentary lifestyle or unknown causes that result in ectopic fat storage with higher cardiometabolic risk $[50,51]$. In women, on the other hand, a risk gradient was

Table 5 Age-adjusted odds ratio of suboptimal waist circumference and abdominal obesity for cardiovascular risk factors by sex

\begin{tabular}{|c|c|c|c|c|c|c|c|c|}
\hline & \multicolumn{8}{|c|}{ Waist circumference } \\
\hline & \multicolumn{4}{|c|}{$\geq 94$ and $<102$ in men, and $\geq 80$ and $<88$ in women } & \multicolumn{4}{|c|}{$\geq 102$ in men, and $\geq 88$ in women } \\
\hline & Men & & Women & & Men & & Women & \\
\hline & OR (Cl 95\%) & p-value & OR (Cl 95\%) & p-value & OR (Cl 95\%) & p-value & OR (Cl 95\%) & p-value \\
\hline Age (1 year) & $1.03(1.03-1.04)$ & $<0.001$ & $1.05(1.04-1.06)$ & $<0.001$ & $1.05(1.05-1.06)$ & $<0.001$ & $1.10(1.10-1.11)$ & $<0.001$ \\
\hline Diabetes & $1.54(1.32-1.79)$ & $<0.001$ & $1.36(1.04-1.80)$ & $<0.001$ & $2.48(2.17-2.85)$ & $<0.001$ & $3.86(3.09-4.89)$ & $<0.001$ \\
\hline Hypertension & $1.78(1.60-1.97)$ & $<0.001$ & $1.45(1.26-1.66)$ & $<0.001$ & $3.51(3.18-3.88)$ & $<0.001$ & $3.61(3.21-4.07)$ & $<0.001$ \\
\hline Hypercholesterolemia & $1.42(1.29-1.56)$ & $<0.001$ & $1.22(1.08-1.37)$ & $<0.001$ & $1.50(1.37-1.65)$ & $<0.001$ & $1.30(1.17-1.44)$ & $<0.001$ \\
\hline Coronary risk (1 percentage point) & $1.10(1.07-1.12)$ & $<0.001$ & $1.34(1.27-1.42)$ & $<0.001$ & $1.17(1.15-1.19)$ & $<0.001$ & $1.71(1.62-1.79)$ & $<0.001$ \\
\hline
\end{tabular}

Prevalence of hypertension, diabetes and hypercholesterolemia was considered if the participant has been already diagnosed, was treated for these disorders or presented with systolic blood pressure $\geq 140 \mathrm{mmHg}$ or diastolic blood pressure $\geq 90 \mathrm{mmHg}$, glycaemia $\geq 126 \mathrm{mg} / \mathrm{dl}$ or total cholesterol $\geq 240 \mathrm{mg} / \mathrm{dl}$, respectively. 
Table 6 Age-adjusted odds ratio of waist-to-height ratio $\geq 0.5$ for cardiovascular risk factors by sex

\begin{tabular}{|c|c|c|c|c|}
\hline & \multicolumn{4}{|c|}{ Waist-to-height ratio $\geq 0.5$} \\
\hline & \multicolumn{2}{|c|}{ Men } & \multicolumn{2}{|c|}{ Women } \\
\hline & OR (Cl 95\%) & p-value & OR (Cl 95\%) & $\mathrm{p}$-value \\
\hline Age (1 year) & $1.08(1.07-1.09)$ & $<0.001$ & $1.10(1.10-1.11)$ & $<0.001$ \\
\hline Diabetes & $2.72(2.04-3.62)$ & $<0.001$ & $2.73(2.16-3.44)$ & $<0.001$ \\
\hline Hypertension & $2.94(2.52-3.43)$ & $<0.001$ & $3.02(2.66-3.42)$ & $<0.001$ \\
\hline Hypercholesterolemia & $1.81(1.58-2.08)$ & $<0.001$ & $1.36(1.23-1.51)$ & $<0.001$ \\
\hline Coronary risk (1 percentage point) & $1.27(1.22-1.32)$ & $<0.001$ & $1.68(1.59-1.77)$ & $<0.001$ \\
\hline
\end{tabular}

Reference value: Waist-to-height ratio $<0.5$. Model adjusted for age.

Prevalence of hypertension, diabetes and hypercholesterolemia was considered if the participant had been diagnosed, was treated for these disorders or presented with systolic blood pressure $\geq 140 \mathrm{mmHg}$ or diastolic blood pressure $\geq 90 \mathrm{mmHg}$, glycaemia $\geq 126 \mathrm{mg} / \mathrm{dl}$ or total cholesterol $\geq 240 \mathrm{mg} / \mathrm{dl}$, respectively.

found between BMI and both WC and WHtR. Therefore, we believe that both types of obesity should now be measured in the clinical setting.

\section{Strengths and limitations}

The DARIOS Study includes 11 studies conducted in different regions of Spain in the first decade of the $21^{\text {st }}$ century. All these studies used standardized methodology. The DARIOS data is drawn from 10 Autonomous
Communities that comprise approximately $70 \%$ of the total Spanish population aged 35-74 years. In addition, the sample size ( $>28,000$ individuals) and response rate $(>70 \%$ in 8 out of 11 studies) ensure that our results accurately reflect the prevalence of obesity in Spain. The response rate was estimated according to the cooperation rate in the 2011 guidelines of The American Association for Public Opinion Research [52].

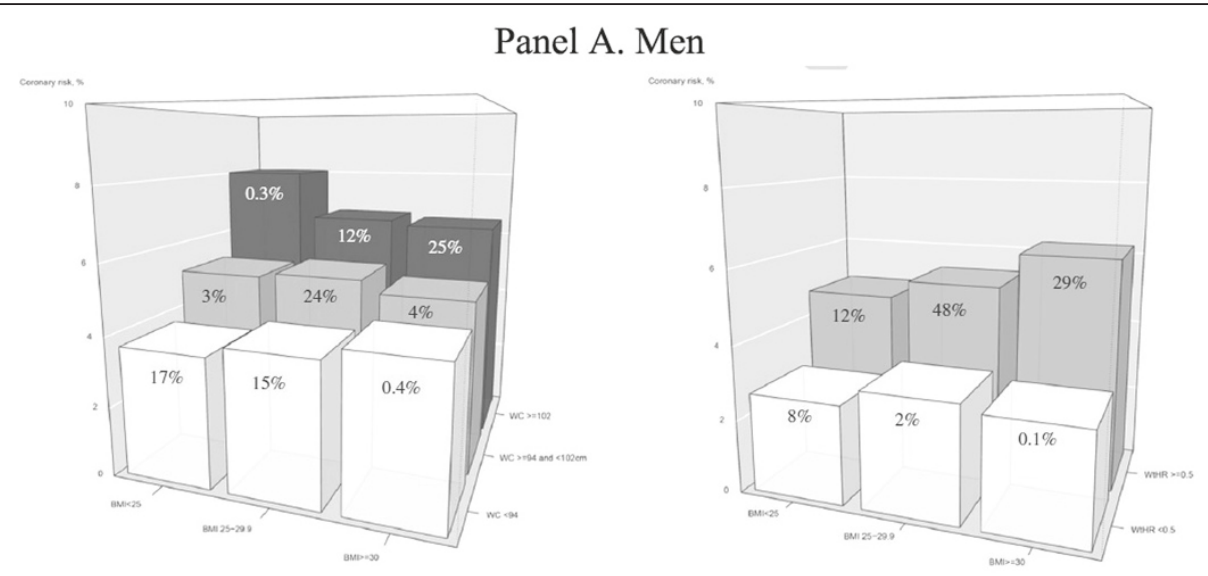

Panel B. Women
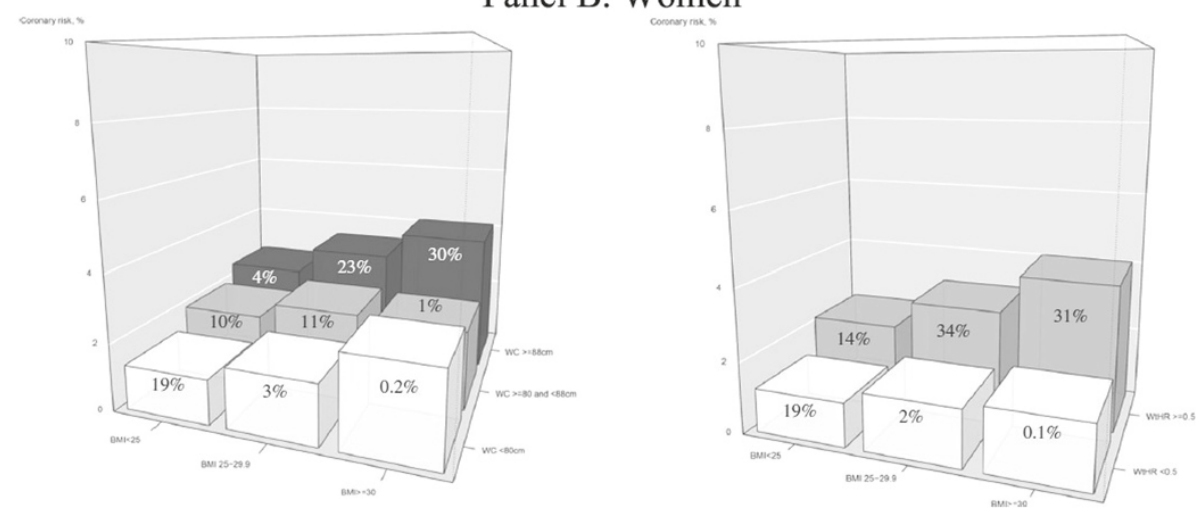

Figure 1 Coronary risk according to body mass index and waist circumference (left) and waist-to-height ratio (right) categories in men (Panel A) and in women (Panel B). 
The cross-sectional design of the study limits the causal interpretation of the associations described. Therefore, cohort studies are needed to ascertain the role of obesity in the incidence of coronary events, particularly in our society, where the prevalence of this cardiovascular risk factor has dramatically increased in recent years [3]. Notably, the cut-off point 0.55 for WHtR has shown higher predictive value for assessing the risk of diabetes and cardiovascular events $[10,53]$.

\section{Conclusion}

The prevalence of general and abdominal obesity in Spain was high: $28 \%$ of men and women presented weight values above those recommended for their height. On the other hand, the prevalence of increased WC was 36\% and 55\% in men and women, respectively. Diabetes, hypertension, hypercholesterolemia and 10-year coronary risk were significantly associated with all categories of general and abdominal obesity. Therefore, these lower cut-off points for both BMI and particularly WC could be used to identify the population at risk and effective preventive measures.

\section{Additional file}

Additional file 1: Table S1. Anthropometric measurements in men, standardized to the European population. Table S2. Anthropometric measurements in women standardized to the European population. Table S3. Baseline characteristics by sex and categories of waist-to-height ratio.

\section{Abbreviations}

BMI: Body mass index; HDL: High-density lipoprotein; LDL: Low-density lipoprotein; WC: Waist circumference.

\section{Competing interests}

The authors declare that they have no competing interests.

\section{Authors' contributions}

FJF participated in the design of the study and wrote the manuscript. MG performed the statistical analysis and participated in the manuscript writing. $J M B$ participated in the design of the study and in the data collection. The other authors provided data and participated in the critical appraisal of the manuscript. All authors read and approved the final manuscript.

\section{Acknowledgments}

The authors wish to thank Jaume Marrugat for the expert revision of the manuscript content and Susanna Tello, Marta Cabañero and Leny Franco for their contribution to the data management of this project. We also appreciate the revision of the English text by Elaine Lilly, PhD, of Writer's First Aid.

This study was financed in its entirety with unconditional support from AstraZeneca. Data from the original component studies was obtained with financial support from: FEDER, Ministerio de Ciencia e Innovación, Instituto de Salud Carlos III (Programa HERACLES RD12/0042; Fondos para investigación. Acuerdo del Consejo Interterritorial de 8 de abril de 2003; EMER07/046 RCESP C3/09); Fondo de Investigación Sanitaria (FIS-FEDER) (PI01/0711, PI02/1158, PI02/1179, PI02/1717, PI03/20471, PI05/2364, PI05/ 2751, PI07/040, PI07/0934, PI07/1213, G03-045, FIS ETES 2007, CP06/00100, CM12/03287); Ministerio de Sanidad y Consumo, Plan Nacional I + D + i 2004-7 (IP071218); Agència de Avaluació de Tecnologia i Recerca Mèdica (034/33/02): Agència de Gestió d'Ajuts Universitaris i de Recerca (2005SGR00577); Departament de Salut de la Generalitat de Catalunya; Fundación Canaria de Investigación y Salud (45/98); Departamento de Salud del Gobierno de Navarra; Junta de Castilla y León; Beca Intensificación de la investigación (INT 07/289); Subdirección General de Promoción de la salud y Prevención. Consejería de Sanidad de la Comunidad de Madrid; Govern Balear; Servicio Andaluz de Salud; Programa de Iniciativa Comunitaria INTERREG IIIA (SP5.E51); Consejería de Salud de la Junta de Andalucía, Ayuda a Proyectos de Investigación (290/04 y 036/06); Sociedad Andaluza de Medicina Familiar y Comunitaria (SAMFYC 2008); Sociedad Española de Medicina de Familia y Comunitaria (semFYC 2009); Consejería de Sanidad y Consumo de la Región de Murcia; Consejería de Salud y Bienestar Social, Junta de Comunidades de Castilla-La Mancha.

\section{Author details}

${ }^{1}$ Centro de Salud Villanueva Norte, Servicio Extremeño de Salud, Villanueva de la Serena, Badajoz, Spain. ${ }^{2}$ Unidad de Investigación Grimex. Programa de Investigación en Enfermedades Cardiovasculares PERICLES, Villanueva de la Serena, Badajoz, Spain. ${ }^{3}$ Grupo de Epidemiología y Genética Cardiovascular, Programa de Investigación en Procesos Inflamatorios y Cardiovasculares, IMIM (Institut Hospital del Mar d'Investigacions Mèdiques), Barcelona, Spain. ${ }^{4}$ Centre d'Atenció Primària La Marina. Unitat de Recerca Barcelona Ciutat, Institut de Recerca en Atenció Primària Jordi Gol, Institut Català de la Salut, Barcelona, Spain. ${ }^{5}$ Unidad de Investigación de Atención Primaria y del Hospital Universitario Señora de Candelaria. Medicina Preventiva y Salud Pública, Universidad de La Laguna, Santa Cruz de Tenerife, Spain. ${ }^{6}$ Grupo de Investigación Riesgo Vascular en Navarra (RIVANA), Servicio de Investigación, Innovación y Formación Sanitaria, Departamento de Salud, Gobierno de Navarra, Pamplona, Spain. ${ }^{7}$ Centro de Salud Riu Nord- Riu Sud, Santa Coloma de Gramenet, Barcelona. ${ }^{8}$ USR Metropolitana Nord, IDIAP Jordi Gol, Mataró, Spain. ${ }^{9}$ Dirección General de Salud Pública e Investigación, Desarrollo e Innovación, Consejería de Sanidad de la Junta de Castilla y León, Valladolid, Spain. ${ }^{10}$ Hospital Universitario Infanta Cristina, Badajoz, Spain. ${ }^{11}$ Servicio de Epidemiologia, Dirección General de Atención Primaria, Consejería de Sanidad Comunidad de Madrid, Madrid, Spain. ${ }^{12}$ Grupo Cardiovascular de Baleares redIAPP, UB Génova. C. S. Sana Agustín, Palma de Mallorca, Baleares, Spain. ${ }^{13}$ Plan Integral de Diabetes de Andalucía, Servicio Andaluz de Salud. CIBER de Fisiopatología de la Obesidad y Nutrición (CIBERobn), Instituto de Salud Carlos III, Madrid, Spain. ${ }^{14}$ Servicio de Epidemiología, Consejería de Sanidad y Política Social de Murcia, Departamento de Ciencias Sociosanitarias, Universidad de Murcia.CIBER de Epidemiologia y Salud Pública (CIBERESP), Murcia, Spain. ${ }^{15}$ Instituto de Ciencias de la Salud, Talavera de la Reina, Toledo, Spain. ${ }^{16}$ Hospital Don Benito-Villanueva, Don Benito, Badajoz, Spain

Received: 21 November 2012 Accepted: 29 May 2013 Published: 5 June 2013

\section{References}

1. World Health Statistics: World Health Organization. Geneva; 2011. http:// www.who.int/ncd_surveillance/infobase/web/InfoBaseCommon/.

2. Flores-Mateo G, Grau M, O'Flaherty M, Ramos R, Elosua R, Violan-Fors C, Quesada M, Martí R, Sala J, Marrugat J, Capewell S: Analyzing the coronary heart disease mortality decline in a Mediterranean population: Spain 1988-2005. Rev Esp Cardiol 2011, 64(11):988-996.

3. Grau M, Subirana I, Elosua R, Solanas P, Ramos R, Masiá R, Cordón F, Sala J, Juvinyà D, Cerezo C, Fitó M, Vila J, Covas Ml, Marrugat J: Trends in cardiovascular risk factor prevalence (1995-2000-2005) in northeastern Spain. Eur J Cardiovasc Prev Rehabil 2007, 14(5):653-659.

4. Schröder H, Elosua R, Vila J, Marti H, Covas MI, Marrugat J: Secular trends of obesity and cardiovascular risk factors in a Mediterranean population. Obesity (Silver Spring) 2007, 15(3):557-562.

5. García-Alvarez A, Serra-Majem L, Ribas-Barba L, Castell C, Foz M, Uauy R, Plasencia A, Salleras L: Obesity and overweight trends in Catalonia, Spain (1992-2003): gender and socio-economic determinants. Public Health Nutr 2007, 10(11A):1368-1378.

6. Divisón Garrote JA, Massó Orozco J, Carrión Valero L, López Abril J, Carbayo Herencia JA, Artigao Rodenas LM, Gil Guillén V, Grupo de Enfermedades Vasculares de Albacete (GEVA): Trends in prevalence of risk factors and global cardiovascular risk in general population of Albacete, Spain (1992-94 a 2004-06). Rev Esp Salud Publica 2011, 85(3):275-284

7. Prospective Studies Collaboration: Body-mass index and cause-specific mortality in 900000 adults: collaborative analisys of 57 prospective studies. Lancet 2009, 373:1083-1096. 
8. Yusuf S, Hawken S, Ounpuu S, Bautista L, Franzosi MG, Commerford P, INTERHEART study investigators, et al: Obesity and the risk of myocardial infarction in 27,000 participants from 52 countries: a case-control study. Lancet 2005, 366(9497):1540-1549.

9. Donini LM, Savina C, Gennaro E, De Felice MR, Rosano A, Pandolfo MM, Del Balzo V, Cannella C, Ritz P, Chumlea WC: A systematic review of the literature concerning the relationship between obesity and mortality in the elderly. J Nutr Health Aging 2012, 16(1):89-98.

10. Schneider HJ, Friedrich $N$, Klotsche J, Pieper $L$, Nauck $M$, John U, Dörr $M$, Felix S, Lehnert H, Pittrow D, Silber S, Völzke H, Stalla GK, Wallaschofski $H_{\text {, }}$ Wittchen HU: The predictive value of different measures of obesity for incident cardiovascular events and mortality. J Clin Endocrinol Metab 2010, 95(4):1777-1785.

11. Gutiérrez-Fisac JL, Guallar-Castillón P, León-Muñoz LM, Graciani A Banegas JR, Rodríguez-Artalejo F: Prevalence of general and central obesity in the adult population of Spain, 2008-2010: the ENRICA study. Obes Rev 2012, 13(4):388-392.

12. Gomez-Cabello A, Pedrero-Chamizo R, Olivares PR, Luzardo L, Juez-Bengoechea A, Mata E, Albers U, Aznar S, Villa G, Espino L, Gusi N, Gonzalez-Gross M, Casajus JA, Ara I, EXERNET Study Group: Prevalence of overweight and obesity in non-institutionalized people aged 65 or over from Spain: the elderly EXERNET multi-centre study. Obes Rev 2011, 12(8):583-592.

13. Gomez-Huelgas R, Mancera-Romero J, Bernal-Lopez MR, Jansen-Chaparro S, Baca-Osorio AJ, Toledo E, Perez-Gonzalez R, Guijarro-Merino R, Tinahones FJ, Martinez-Gonzalez MA: Prevalence of cardiovascular risk factors in an urban adult population from southern Spain. IMAP Study. Int I Clin Pract 2011, 65(1):35-40.

14. Escribano García S, Vega Alonso AT, Lozano Alonso J, Alamo Sanz R, Lleras Muñoz S, Castrodeza Sanz J, Gil Costa M, Study of Cardiovascular Risk in Castile and Leon, Spain: Obesity in Castile and Leon, Spain: epidemiology and association with other cardiovascular risk factors. Rev Esp Cardiol 2011, 64(1):63-66.

15. Aguilera-Zubizarreta E, Ugarte-Miota T, Muñoz Cacho P, Vara-González L, Sanz de Castro S, Grupo CANHTABRIA: Prevalence of overweight and obesity in Cantabria [Spain]. Gac Sanit 2008, 22(5):461-464.

16. López Suárez A, Elvira González J, Beltrán Robles M, Alwakil M, Saucedo JM Bascuñana Quirell A, Barón Ramos MA, Fernández PF: Prevalence of obesity, diabetes, hypertension, hypercholesterolemia and metabolic syndrome in over 50-year-olds in Sanlúcar de Barrameda. Spain. Rev Esp Cardiol 2008, 61(11):1150-1158.

17. Félix-Redondo FJ, Baena-Díez JM, Grau M, Tormo MÁ, Fernández-Bergés D: Prevalence of obesity and cardiovascular risk in the general population of a health area in Extremadura (Spain): the Hermex study. Endocrinol Nutr 2012, 59(3):160-168.

18. Cristo Rodríguez Pérez MD, Cabrera De León A, Aguirre-Jaime A, Domínguez Coello S, Brito Díaz B, Almeida González D, Borges Alamo C, Castillo Rodríguez JC, Carrillo Fernández L, González Hernández A, Alemán Sánchez JJ: The waist to height ratio as an index of cardiovascular risk and diabetes. Med Clin (Barc) 2010, 134(9):386-391.

19. Marrugat J, Subirana I, Comín E, Cabezas C, Vila J, Elosua R, Nam BH, Ramos R, Sala J, Solanas P, Cordón F, Gené-Badia J, D'Agostino RB VERIFICA Investigators: Validity of an adaptation of the Framingham cardiovascular risk function: the VERIFICA Study. J Epidemiol Community Health 2007, 61(7):40-47

20. Perk J, De Backer G, Gohlke H, Graham I, Reiner Z, Verschuren M, Albus C, Benlian P, Boysen G, Cifkova R, Deaton C, Ebrahim S, Fisher M, Germano G, Hobbs R, Hoes A, Karadeniz S, Mezzani A, Prescott E, Ryden L, Scherer M, Syvänne M, Scholte op Reimer WJ, Vrints C, Wood C, Zamorano JL, Zannad F: European Guidelines on cardiovascular disease prevention in clinical practice (version 2012). The Fifth Joint Task Force of the European Society of Cardiology and Other Societies on Cardiovascular Disease Prevention in Clinical Practice. Eur Heart $\lrcorner$ 2012, 33(13):1635-1701.

21. Grau M, Elosua R, Cabrera De León A, Guembe MJ, Baena-Díez JM, Vega Alonso T, Javier Félix F, Zorrilla B, Rigo F, Lapetra J, Gavrila D, Segura A, Sanz H, Fernández-Bergés D, Fitó M, Marrugat J: Cardiovascular risk factors in Spain in the first decade of the 21st Century, a pooled analysis with individual data from 11 population-based studies: the DARIOS study. Rev Esp Cardiol 2011, 64(4):295-304

22. Alberti KG, Eckel RH, Grundy SM, Zimmet PZ, Cleeman II, Donato KA Fruchart JC, James WP, Loria CM, Smith SC Jr, International Diabetes
Federation Task Force on Epidemiology and Prevention, National Heart, Lung, and Blood Institute, American Heart Association, World Heart Federation, International Atherosclerosis Society, International Association for the Study of Obesity: Harmonizing the metabolic syndrome: a joint interim statement of the International Diabetes Federation Task Force on Epidemiology and Prevention; National Heart, Lung, and Blood Institute; American Heart Association; World Heart Federation; International Atherosclerosis Society; and International Association for the Study of Obesity. Circulation 2009, 120(16):1640-1645

23. Alberti KG, Zimmet P, Shaw J, IDF Epidemiology Task Force Consensus Group: The metabolic syndrome-a new worldwide definition. Lancet 2005, 366(9491):1059-1062.

24. Lee CMY, Huxley RR, Wildman RP, Woodward M: Indices of abdominal obesity are better discrimantors of cardiovascular risk factors than BMI: a meta-analysis. J Clin Epidemiol 2008, 61(7):646-653.

25. Ashwell M, Hsieh SD: Six reasons why the waist-to-height ratio is a rapid and effective global indicator for health risks of obesity and how its use could simplify the international public health message on obesity. Int J Food Sci Nutr 2005, 56(5):303-307.

26. Ahmad OE, Boschi-Pinto C, López AD, Murray CJL, Lozano R, Inoue M: Age standardization of rates: a new WHO standard GPE. Discussion Paper Series: No. 31. Geneva: World Health Organization; 2000

27. Aranceta-Bartrina J, Serra-Majem L, Foz-Sala M, Moreno-Esteban B, Grupo Colaborativo SEEDO: Prevalence of obesity in Spain. Med Clin (Barc) 2005, 125(12):460-466.

28. Gutiérrez-Fisac JL, López E, Banegas JR, Graciani A, Rodríguez-Artalejo F: Prevalence of overweight and obesity in elderly people in Spain. Obes Res 2004, 12(4):710-715.

29. Cea-Calvo L, Moreno B, Monereo S, Gil-Guillén V, Lozano JV, Martí-Canales JC, Llisterri JL, Aznar J, González-Esteban J, Redón J, PREV-ICTUS Study: Prevalence and related factors of overweight and obesity in Spanish population aged 60 years-old or older. The PREV-ICTUS study. Med Clin (Barc). 2008, 131(6):205-210.

30. Doak CM, Wijnhoven TM, Schokker DF, Visscher TL, Seidell JC: Age standardization in mapping adult overweight and obesity trends in the WHO European Region. Obes Rev 2012, 13(2):174-191.

31. Wang $Y$, Beydoun MA: The obesity epidemic in the United Statesgender, age, socioeconomic, racial/ethnic, and geographic characteristics: a systematic review and meta-regression analysis. Epidemiol Rev 2007, 29:6-28.

32. Nolan CJ, Damm P, Prentki M: Type 2 diabetes across generations: from pathophysiology to prevention and management. Lancet 2011, 378(9786):169-181.

33. Zalesin KC, Franklin BA, Miller WM, Peterson ED, McCullough PA: Impact of obesity on cardiovascular disease. Endocrinol Metab Clin North Am 2008, 37(3):663-684.

34. Bamba V, Rader DJ: Obesity and atherogenic dyslipidemia. Gastroenterology 2007, 132(6):2181-2190.

35. Meisinger C, Döring A, Thorand B, Heier M, Löwel H: Body fat distribution and risk of type 2 diabetes in the general population: are there differences between men and women? The MONICA/KORA Augsburg cohort study. Am J Clin Nutr 2006, 84(3):483-489.

36. Cabrera De León A, Rodríguez-Pérez Mdel C, Rodríguez-Benjumeda LM, Anía-Lafuente B, Brito-Díaz B, Muros De Fuentes M, Almeida-González D, Batista-Medina M, Aguirre-Jaime A: Sedentary lifestyle: physical activity duration versus percentage of energy expenditure. Rev Esp Cardiol 2007, 60(3):244-250.

37. Power ML, Schulkin J: Sex differences in fat storage, fat metabolism, and the health risks from obesity: possible evolutionary origins. $\mathrm{Br} J \mathrm{Nutr}$ 2008, 99(5):931-940.

38. Provencher V, Drapeau V, Tremblay A, Després JP, Lemieux S: Eating behaviors and indexes of body composition in men and women from the Québec family study. Obes Res 2003, 11(6):783-792.

39. Van Dis I, Geleijnse JM, Kromhout D, Boer JM, Boshuizen H, Verschuren WM: Do obesity and parental history of myocardial infarction improve cardiovascular risk prediction? Eur J Prev Cardiol, in press.

40. Pischon T, Boeing $H$, Hoffmann K, Bergmann M, Schulze MB, Overvad K, van der Schouw YT, Spencer E, Moons KG, Tjønneland A, Halkjaer J, Jensen MK, Stegger J, Clavel-Chapelon F, Boutron-Ruault MC, Chajes V Linseisen J, Kaaks R, Trichopoulou A, Trichopoulos D, Bamia C, Sieri S, Palli D, 
Tumino R, Vineis P, Panico S, Peeters PH, May AM, Bueno-de-Mesquita HB, van Duijnhoven FJ, Hallmans G, Weinehall L, Manjer J, Hedblad B, Lund E, Agudo A, Arriola L, Barricarte A, Navarro C, Martinez C, Quirós JR, Key T, Bingham S, Khaw KT, Boffetta P, Jenab M, Ferrari P, Riboli E: General and abdominal adiposity and risk of death in Europe. N Engl J Med 2008, 359(20):2105-20.

41. Grau M, Subirana I, Elosua R, Fitó M, Covas MI, Sala J, Masiá R, Ramos R, Solanas P, Cordon F, Nieto FJ, Marrugat J, REGICOR Investigators: Why should population attributable fractions be periodically recalculated? An example from cardiovascular risk estimation in southern Europe. Prev Med 2010, 51(1):78-84.

42. Huerta JM, Tormo MJ, Gavrila D, Navarro C: Cardiovascular risk estimated after 13 years of follow-up in a low-incidence Mediterranean region with high-prevalence of cardiovascular risk factors. BMC Public Health 2010, 10:640.

43. Wilson PW, D'Agostino RB, Sullivan L, Parise H, Kannel WB: Overweight and obesity as determinants of cardiovascular risk: the Framingham experience. Arch Intern Med 2002, 162(16):1867-72.

44. Lemieux I, Poirier P, Bergeron J, Alméras N, Lamarche B, Cantin B, Dagenais GR, Després JP: Hypertriglyceridemic waist: a useful screening phenotype in preventive cardiology? Can J Cardiol 2007, 23(Suppl B):23B-31B.

45. Qiao Q, Nyamdorj R: Is the association of type II diabetes with waist circumference or waist-to-hip ratio stronger than that with body mass index? Eur J Clin Nutr 2010, 64(1):30-4.

46. Porter SA, Massaro JM, Hoffmann U, Vasan RS, O'Donnel CJ, Fox CS: Abdominal subcutaneous adipose tissue: a protective fat depot? Diabetes Care 2009, 32(6):1068-75.

47. Zamboni M, Mazzali G, Fantin F, Rossi A, Di Francesco V: Sarcopenic obesity: a new category of obesity in the elderly. Nutr Metab Cardiovasc Dis 2008, 18(5):388-95.

48. Chung JY, Kang HT, Lee DC, Lee HR, Lee YJ: Body composition and its association with cardiometabolic risk factors in the elderly: A focus on sarcopenic obesity. Arch Gerontol Geriatr 2013, 56(1):270-8.

49. Coutinho T, Goel K, Corrêa de Sá D, Carter RE, Hodge DO, Kragelund C, Kanaya AM, Zeller M, Park JS, Kober L, Torp-Pedersen C, Cottin Y, Lorgis L, Lee SH, Kim YJ, Thomas R, Roger VL, Somers VK, Lopez-Jimenez F: Combining body mass index with measures of central obesity in the assessment of mortality in subjects with coronary disease: role of "normal weight central obesity". J Am Coll Cardiol 2013, 61(5):553-60

50. Després JP, Lemieux I, Bergeron J, Pibarot P, Mathieu P, Larose E, Rodés-Cabau J, Bertrand OF, Poirier P: Abdominal obesity and the metabolic syndrome: contribution to global cardiometabolic risk. Arterioscler Thromb Vasc Biol 2008, 28(6):1039-49.

51. Britton KA, Fox CS: Ectopic fat depots and cardiovascular disease. Circulation 2011, 124(24):e837-41.

52. The American Association for Public Opinion Research: Standard Definitions: Final dispositions of case codes and outcomes rates for surveys. 7th edition; 2011. Available at: http://www.aapor.org/Home.htm.

53. de León AC, Coello SD, González DA, Díaz BB, Rodríguez JC, Hernández AG, Aguirre-Jaime A, Pérez M del C: Impaired fasting glucose, ancestry and waist-to-height ratio: main predictors of incident diagnosed diabetes in the Canary Islands. Diabet Med 2012, 29(3):399-403.

doi:10.1186/1471-2458-13-542

Cite this article as: Félix-Redondo et al:: Prevalence of obesity and associated cardiovascular risk: the DARIOS study. BMC Public Health 2013 13:542.

\section{Submit your next manuscript to BioMed Central and take full advantage of:}

- Convenient online submission

- Thorough peer review

- No space constraints or color figure charges

- Immediate publication on acceptance

- Inclusion in PubMed, CAS, Scopus and Google Scholar

- Research which is freely available for redistribution 